\title{
INTRODUCTION
}

\section{Female Genital Mutilation}

Female Genital Mutilation (FGM) also referred to as 'cutting' (WHO 2012) has become an area of increasing concern in the UK and other developed countries due to migration, particularly from Sub-Saharan Africa (Bewley et al. 2010). However in the 28 countries for which statistics are available, the incidence varies considerably from under $1 \%$ of the female population in Uganda to almost $98 \%$ of women in Somalia (WHO 2012). It can be assumed therefore, that prevalence in the UK and other Western countries is closely related to patterns of migration and asylum. While FGM has been illegal in the UK since 1985, and taking children abroad for the procedure a criminal offence since 2003, British born girls are still being cut, with 112 cases reported in 2016-2017 (Moffat 2017). All together over 5000 new cases were reported during the same time span, although most of these were in girls and women born outside the UK. Research by City University in 2015 estimated that there are over 100,000 women between the ages of 15-49 who have had FGM, currently living in the UK (Cook 2016). Such statistics demonstrate the importance of ongoing investigation into how and where girls and women are being subjected to FGM, despite current legislation prohibiting both the procedure and foreign travel for the purpose of FGM.

This issue is of concern to all health professionals who may be involved in protecting the health of girls and women. However, midwives, whose remit is reproductive health, have a particular responsibility as they often make the initial contact with women from minority ethnic communities where FGM is prevalent.

Midwives are educated to be skilled communicators and to engage with women empathetically within a framework of cultural, ethnic and religious diversity. What midwives may lack, however, is an understanding of the legal requirements regarding accountability for documenting and/or 
reporting cases of FGM or safeguarding responsibilities where there are concerns that a family may wish to have an infant, pre-adolescent or adolescent daughter 'cut', either by a practitioner in the UK, or while travelling abroad.

Both instances are illegal under UK law. This article should interest all health professionals by increasing their understanding of the legal implications of FGM and how UK police authorities have responded to changes in the law. It will be of particular interest to midwives wishing to deepen their understanding of the legal and ethical implications attached to FGM in addition to the physical, social and psychological implications with which they may already be familiar.

\section{Focus of this paper}

This paper focusses on data collection for Female Genital Mutilation (FGM) since the introduction of mandatory recording and reporting by the Serious Crime Act 2015 which amended the original legislation.

Point 55 from the UK Government Violence against Women and Girls Strategy 2016 2020 action plan reads as follows:

\footnotetext{
"Develop an approach to the collection of data recorded by Police Authorities in relation to Honour Based Violence (HBV), Forced Marriage (FM) and Female Genital Mutilation (FGM) in conjunction with the National Police Chiefs' Council. Consideration will be given to this data being recorded as part of the Annual Data Return." (Home Office lead, June 2016 delivery date) (UK Parliament 2016)
}

\section{Legislation}


The Female Genital Mutilation Act 2003 defines Female genital mutilation (FGM), as any procedure where a person 'excises, infibulates or otherwise mutilates the whole or any part of a girl's labia majora, labia minora or clitoris' (UK Parliament 2003). This is consistent with World Health Organisation guidance (WHO 2017). Performing a procedure with such results is a criminal offence where performed on a female of any age. Liability falls on the cutter, accessories and, in rare cases, the female herself. The provisions cover acts performed in England and Wales or overseas (as long as the girl is a UK resident) (UK Parliament 2003). The change from citizen to resident in 2014 provided protection for all female children in the UK. There is an exception in the legislation (Sections 1(2) and 1(3)), for operations by approved practitioners as part of childbirth or necessary for her physical or mental health (UK Parliament 2003). In the context of what may be necessary, it is immaterial whether she or any other person believes that the operation is required as a matter of custom or ritual. However, if a woman requires cutting in an obstetric setting in order to facilitate childbirth, under the law midwives and obstetricians may not return a woman's vulva to the infibulated state that existed prior to opening for childbirth (Rashid and Rashid 2007).

\section{Health consequences of FGM}

The immediate health consequences of FGM include severe pain, significant risk of damage to the urinary tract, bleeding, infection, and possibly death. Long-term consequences include chronic pain, painful intercourse, urinary incontinence, recurrent urinary tract infections, complications of childbirth, and keloid scar formation (WHO 2017). Complications of childbirth include obstructed labour, fetal hypoxia, stillbirth, severe perineal tears, infection and haemorrhage (Rashid and Rashid 2007). For this reason maternity care providers recommend early identification of women who have undergone FGM so that prenatal de-infibulation can be offered. While this cannot restore the vulva to its original state, it reveals the vaginal and 
urethral openings thereby reducing complications during childbirth. This should be done by week 20 of the pregnancy to ensure healing prior to giving birth (Albert et al. 2015).

\section{Incidence and prevalence of FGM}

In 2011 it was estimated that 137000 women and girls affected by FGM lived in England and Wales (Macfarlane and Dorkenoo 2015) (UK Parliament 2016). More recently, there were 5391 new cases of FGM recorded in England and Wales from April 2016 to March 2017, and FGM was most commonly performed when the victim was a child aged between 5 and 9 years old (HSCIC 2017). Modern guidance is to treat FGM as a form of child abuse (NSPCC 2018). Investigations have included an unsuccessful prosecution of a medical practitioner (Rogers 2015).

\section{What is the difference between Mandatory Reporting of FGM and Mandatory Recording of FGM?}

\section{Mandatory reporting of FGM}

Health and social care professionals and teachers have had a mandatory duty to report FGM cases to the police since October 2015 (UK Home Office 2016). Mandatory reporting applies in cases when either a girl informs the professional that FGM has been carried out on her, or when a professional observes physical signs consistent with FGM. The duty only applies when the girl is aged under 18 years of age at the time of disclosure or identification. Following receipt of a report, police should initiate a multi-agency response in line with local safeguarding arrangements. Data is currently limited as to whether mandatory reporting, in the manner which it is currently applied, is successfully safeguarding girls and women at risk of FGM in the UK.

\section{Mandatory recording of FGM}


Separate from the duty of mandatory reporting to police, there is also a duty of mandatory recording. As of April 2015, all acute NHS Trusts and GPs have a duty to submit details of all diagnosed FGM cases, in girls and women of any age, to the Health and Social Care Information Centre (HSCIC) (NHS England 2015). The data collected by the HSCIC is comprehensive; it includes anonymized patient demographic information, the type of FGM identified, the age at presentation and the age at which FGM was done, family history of FGM, and limited obstetric history (HSCIC 2017). It also includes whether or not the woman has any daughters. This data has invaluably aided our understanding of the prevalence of FGM in the UK, particularly in locating vulnerable populations and in highlighting the extent of the problem in this country. Since the current form of mandatory reporting to the police only applies in relation to girls under the age of 18 , as of yet it remains to be seen how the HSCIC data of recorded cases of FGM will be used to influence policy and protect all of the vulnerable people identified.

In essence, the Mandatory Reporting duty, on individuals, is about reporting a crime in relation to a child aged under 18 years of age (NHS England 2015). The Mandatory Recording duty, on organisations, is about collecting and recording data on FGM, including of children aged under 18 years of age and adults aged over 18 years of age many of whom, if they have undergone FGM, will have had this performed as a child.

\section{History of criminal investigations}

Where criminal investigations have taken place, barriers to formal charges/prosecution have included (Simpson et al. 2012):

1. Girls being unwilling to testify against parents or community members 
2. The victim or the accused alleging that FGM took place prior to their becoming resident

3. Lack of knowledge about FGM by healthcare or police workers, leading it to be labeled a 'cultural issue'.

A prosecution follows an act(s) of mutilation so agencies including Amnesty International advocate that the prevention of FGM should be prioritised through a collective approach which involves raising awareness on women's rights, on the impact of the practice on women and on the community as a whole with the aim of a collective abandonment of the practice (Amnesty International EU Office 2011).

\section{FGM preventative action}

One example of preventive action taken in relation to FGM is the Project Azure, a UK based initiative in which the London Metropolitan Police Service (Metropolitan Police Service 2010) joins forces with partner agencies to reach out to families from FGM practising communities. Project Azure aims to educate parents and families about the health and legal implications of FGM while simultaneously empowering children at risk for the practice (Metropolitan Police Service 2018).

\section{Why is scientific analysis of FGM data important?}

Given that healthcare and human rights experts have raised concerns regarding barriers to its success and alternative strategies, it is imperative that we scientifically analyse the data on FGM reporting from Police Authorities in the UK as by understanding the impact of mandatory reporting and recording of FGM, we can consider whether the incidence of FGM has decreased since mandatory reporting and recording were introduced as well as consider what changes, if any, may be required to the current FGM legal reporting requirements. 
This study was designed to look at the number of FGM cases that were reported to the police prior to the introduction of the mandatory reporting of FGM in the UK in October 2015 and following the introduction of that legislation to try and, initially, ascertain what impact that legislation had had on the reporting of FGM. This was a precursor to using the data supplied to conduct an impact and outcome evaluation of the introduction of the FGM-reporting legislation. 


\section{METHOD}

E-mail requests were sent to all 45 UK Police Authorities (Anon., n.d.) under the provisions set out in the Freedom of Information Act 2000, asking the following three questions:

\section{$\underline{\text { Request One }}$}

Please supply data on how many cases of Female Genital Mutilation (FGM) were reported to your police force each month between 31 October 2015 and today's date (21 February 2016), stratified, if possible, by age of alleged victim and occupation of person making the report?

\section{$\underline{\text { Request Two }}$}

Please can you supply data on how many cases of FGM were reported to your police force each month between 31 October 2014 and 31 October 2015, stratified, if possible, by age of alleged victim and occupation of person making the report?

\section{Request Three}

Please can you supply data on the age-breakdown, sex-breakdown and total population of your police force area in 2014 and 2015? If it is not possible, or you do not hold this data, please let me know as I would not wish this to detract from the above two requests.

The nature of the above FOIA requests was designed to obtain information about cases of FGM reported to the Police under the individual Mandatory Reporting Duty.

Similar requests were also sent to NHS England, the Home Office, the Health and Social Care Information Centre and the Department of Health (London) asking how many cases of FGM had been reporting to their organisations within the above timescales. The nature of these requests was to obtain information on FGM which may have been reported under the organisational 
Mandatory Recording Duty. The Office of National Statistics was asked to supply data on the age-breakdown, sex-breakdown and total population of each local authority area.

\section{Analysis of FGM data from Police Forces}

Where FGM data was received from Police Forces ("Police Authorities”), it was entered into an Excel spreadsheet for analysis. Where a rejection notice was given (i.e. no or limited data was supplied) the rejection notice was saved and an internal appeal lodged under the provisions set out in the Freedom of Information Act 2000 (UK Parliament 2000). If data were supplied following a successful internal appeal, those data were included in the Excel spreadsheet. If the appeal was rejected, the reasons were saved.

Data supplied were analysed manually within Microsoft Excel. 


\section{LIMITATIONS}

Formal requests were made to all 45 UK Police Authorities under the Freedom of Information Act 2000 and all internal appeal procedures were followed, where necessary, if a negative response was received to the first request. However, there was no escalation to the Office of the Information Commissioner when internal appeal requests were rejected. Whilst such an appeal to the Office of the Information Commissioner may have been legally possible, the focus of our enquiries was on the ease, or otherwise, with which such important data can be accessed and analysed. Our appeals took on board that the current way in which the data was collected may contain private data which would require ethical approval to access. Our experience was that for an academic attempting to evaluate the introduction of Mandatory Reporting of FGM, or to a member of the public with an interest in this subject area - perhaps as a precursor to expressing a view on the recent 2016 consultation on generic mandatory reporting of child abuse (Department for Education and Home Office 2016) - information on FGM is difficult, if not impossible, to obtain via an easy to access method. The obtaining of such information by a member of the public would have been equally difficult. 


\section{RESULTS}

\section{Organisations providing data}

Out of the 45 Police Authorities in the UK, initially six (13.3\%) Police Authorities provided data in response to the Freedom of Information Act 2000 (FOIA) request. Of these six, three (6.7\%) Police Authorities (British Transport Police, Ministry of Defence Police and Civilian Nuclear Constabulary) reported that zero cases of FGM had been reported to them between 31 October 2014 and 21 February 2016.

Of the initial six Police Authorities supplying data three (6.7\%) Police Authorities disclosed data confirming the number of FGM cases that had been reported to them:

- London Metropolitan Police Service (Table 1)

- Police Scotland (Table 2)

- $\quad$ Greater Manchester Police (Tables 3 \& 4)

Information received from London Metropolitan Police Service

\begin{tabular}{|l|l|l|l|}
\hline & FGM Allegations & FGM Offences & FGM Victims under 18 \\
years of age \\
\hline 2014 & 83 & 17 & 10 \\
\hline 2015 & 117 & 17 & 12 \\
\hline Total & 200 & 34 & 22 \\
\hline
\end{tabular}

Table 1 London Metropolitan Police Services data on FGM

The London Metropolitan Police Services declined to provide data on FGM reporting stratified by month, age of victim, or occupation of person making the report. It is not clear from the data 
provided by The London Metropolitan Police Services in relation to any victims of FGM aged over 18 years of age, whether the FGM was performed as a child or as an adult.

\section{Information received from Police Scotland}

Police Scotland provided a detailed response providing a monthly breakdown of incidents of reported FGM, and separately a breakdown of the ages of the victims overall (Table 2). They could not provide data on the occupation of person reporting FGM. In total Police Scotland had 33 FGM incidents reported to them between October 2014 and February 2016 with 3 of these relating to unborn children at risk of FGM, 28 relating to children aged under 18 years of age and 2 relating to adults aged over 18 years of age. It is not clear from the data provided by Police Scotland in relation to those victims of FGM aged over 18 years of age, whether the FGM was performed as a child or as an adult. 


\begin{tabular}{|l|l|}
\hline Month & $\begin{array}{l}\text { Number of FGM Incidents Reported } \\
\text { to Police Scotland }\end{array}$ \\
\hline Feb-16 & 2 \\
\hline Jan-16 & 1 \\
\hline Dec-15 & 1 \\
\hline Nov-15 & 5 \\
\hline Oct-15 & 0 \\
\hline Sep-15 & 3 \\
\hline Aug-15 & 0 \\
\hline Jul-15 & 2 \\
\hline Jun-15 & 5 \\
\hline May-15 & 1 \\
\hline Apr-15 & 3 \\
\hline Mar-15 & 1 \\
\hline Feb-15 & 3 \\
\hline Jan-15 & 3 \\
\hline Dec-14 & 0 \\
\hline Nov-14 & 3 \\
\hline Oct-14 & 0 \\
\hline TOTAL & 33 \\
\hline
\end{tabular}

Table 2: Police Scotland data on FGM 
Information received from Greater Manchester Police

Greater Manchester Police provided detailed breakdowns of 77 FGM cases reported by month, age of victim, and occupation of person reporting (Table 3 and Table 4).

\begin{tabular}{|l|l|l|l|}
\hline $\begin{array}{l}\text { Age } \\
\text { (years) }\end{array}$ & $\begin{array}{l}\text { Total FGM Victims aged } \\
\text { under 18 years of age }\end{array}$ & $\begin{array}{l}\text { Total FGM Victims aged } \\
\text { over 18 years of age }\end{array}$ & $\begin{array}{l}\text { Total FGM incidents where age } \\
\text { unknown (or relating to an } \\
\text { unborn child) }\end{array}$ \\
\hline Oct-14 & 2 & 2 & 2 \\
\hline Nov-14 & 1 & 0 & 0 \\
\hline Dec-14 & 2 & 0 & 0 \\
\hline Jan-15 & 1 & 0 & 0 \\
\hline Feb-15 & 0 & 0 & 0 \\
\hline Mar-15 & 4 & 0 & 0 \\
\hline Apr-15 & 3 & 0 & 0 \\
\hline May-15 & 1 & 0 & 0 \\
\hline Jun-15 & 2 & 0 & 3 \\
\hline Jul-15 & 8 & 0 & 0 \\
\hline Aug-15 & 6 & 0 & 0 \\
\hline Sep-15 & 1 & 0 & 0 \\
\hline Oct-15 & 10 & 0 & 1 \\
\hline Nov-15 & 6 & 0 & 2 \\
\hline Dec-15 & 6 & 0 & 0 \\
\hline Jan-16 & 6 & 0 & 13 \\
\hline Feb-16 & 3 & 0 & 0 \\
\hline Total & 62 & 0 & 0 \\
\hline
\end{tabular}

Table 3: Greater Manchester Police Number of FGM Reports Stratified by Month and Age of Victim 
It is not clear from the data provided by Greater Manchester Police in relation to those victims of FGM aged over 18 years of age, whether the FGM was performed as a child or as an adult.

\begin{tabular}{|l|l|l|l|l|l|l|l|l|l|}
\hline Occupation & $\begin{array}{l}\text { Charity } \\
\text { worker }\end{array}$ & Midwife & GP & $\begin{array}{l}\text { School } \\
\text { nurse/teacher }\end{array}$ & $\begin{array}{l}\text { Health } \\
\text { visitor }\end{array}$ & $\begin{array}{l}\text { Nurse } \\
\text { nursery } \\
\text { nurse }\end{array}$ & $\begin{array}{l}\text { Social } \\
\text { worker }\end{array}$ & Police \\
\hline TOTAL & 3 & 18 & 4 & 12 & 11 & 2 & 2 & 17 & 8 \\
\hline
\end{tabular}

Table 4: Greater Manchester Police reports of FGM made by various professionals, October 2014-February 2016

Out of the total 45 Police Authorities in the UK, the remaining $39(86.7 \%, n=39 / 45)$ Police Authorities either only supplied partial information, either on initial request or after an Appeal, or refused to supply any information.

\section{Organisations declining to provide information}

Nine $(20 \%)$ initially rejected the FOIA request but either in an initial response, or on Appeal, opted to provide some data as part of their stated duty to assist. Although some data was provided, this did not fully respond to the questions asked within the FOIA request.

\section{Norfolk Constabulary}

The Norfolk Constabulary consented to give only aggregate data on reporting per year. They released that there were 4 incidents of FGM reported to Norfolk Constabulary in 2014, and 13 cases in 2015. Suffolk Constabulary gave identical data. It is not clear if this was pooled data.

\section{North Wales and South Wales Police Authorities}

North Wales and South Wales Police Authorities refused to comment on whether there were any cases reported to them between 31 October 2015 and February 2016, however both Forces 
confirmed that they had zero cases of FGM reported between 31 October 2014 and 31 October 2015.

\section{Police Service of Northern Ireland}

Police Service of Northern Ireland confirmed that they had no cases of FGM reported to them in the $2014 / 2015$ financial year.

\section{Northumbria Police}

Northumbria Police confirmed only that they had 2 cases "deemed to be FGM" in 2015.

\section{Staffordshire Police}

Staffordshire Police confirmed only that there were no recorded crimes of FGM from 31 October 2014 to 31 October 2015, however no mention was given about whether any cases had been reported.

\section{West Yorkshire Police}

West Yorkshire Police recorded 11 crimes relating to FGM between 01 March 2004 and 31 December 2015, though no further date-stratification was provided. Six of the victims of FGM were reported to have been under the age of one year old, one was reported to have been aged one year old, one was reported to have been aged two years old, one was reported to have been aged three years old and two were reported to have been aged eight years old. It is unclear whether the ages refer to the age at time of alleged FGM occurring or the age at time of reporting. The occupation of the person who made the report was not released.

\section{Mersey Police}


Mersey Police reported that they had recorded no crimes under the Female Genital Mutilation Act 2003 in 2014 or 2015.

\section{The Health and Social Care Information Centre}

Health and Social Care Information Centre $(\mathrm{HSClC})$ data comes from mandatory recording in the National Health Service (NHS). The method of storing and analysing the data on the HSCIC server at NHS digital was reported to have changed for 2016. It was not therefore possible to see the number of discrete cases of FGM reported by month after December 2015. The numbers of FGM cases reported in the HSCIC data were vastly different from the (limited number) of FGM cases disclosed by the Police Authorities (Table 5). 


\begin{tabular}{|l|l|}
\hline Date & New reports of \\
& FGM \\
\hline Oct 2014 & 567 \\
\hline Nov 2014 & 550 \\
\hline Dec 2014 & 608 \\
\hline Jan 2015 & 569 \\
\hline Feb 2015 & 528 \\
\hline Mar 2015 & 578 \\
\hline Apr 2015 & 298 \\
\hline May 2015 & 323 \\
\hline Jun 2015 & 415 \\
\hline Jul 2015 & 471 \\
\hline Aug 2015 & 442 \\
\hline Sep 2015 & 472 \\
\hline Oct 2015 & 436 \\
\hline TOTAL cases reported (Oct 2014 - Oct 2015) & 6257 \\
\hline
\end{tabular}

Breakdown of FGM cases reported in the HSCIC data from October 2014 to October 2015

\section{The Office for National Statistics}

The Office for National Statistics reported that since April 2012, FGM has been counted under the police recorded offence category of "8N - Assault with Injury".

This offence category includes other types of assault, other than FGM. Therefore specific data for FGM could not be extracted. 


\section{The Home Office}

The Office for National Statistics advised that the Home Office holds overall responsibility for police-recorded crime data. An enquiry made to the Home Office to ask for release of data regarding FGM cases was responded to stating that FGM is recorded alongside crimes like "assault occasioning actual bodily harm" as an aggregate under category $8 \mathrm{~N}$, and so the Home Office were unable to provide specific data for FGM.

The Home Office did, however, provide data answering Request 3 (total population, broken down by age and gender) with regard to every local authority in England and Wales. This data is freely available through the Office of National Statistics (Office for National Statistics 2017).

\section{NHS England}

NHS England reported that they do not hold any information in relation to FGM cases and advised contact with the Department of Health and the HSCIC.

\section{The UK Department of Health in London ("the Department of Health")}

The Department of Health responded to advise contact could be made with the HSCIC however warned that any data provided by the HSCIC would not be analogous to the number of cases reported under the duty for mandatory reporting. HSCIC data reflects mandatory recording by organisations, not mandatory reporting by individuals.

\section{Organisations declining the request for information under the FOIA}

In total, 39 (86.7\%) out of the total 45 Police Authorities did not provide comprehensive data in response to the FOIA request. Police Authorities who rejected the FOIA request, either initially 
and on Appeal, were not restricted to one alleged ground under the Freedom of Information Act 2000 , as alleged justification of the rejection (Table 6). The relevant Sections of the Freedom of Information Act cited in Table 6 are found in Appendix Two.

\begin{tabular}{|c|c|c|}
\hline $\begin{array}{l}\text { Section of the Freedom of } \\
\text { Information Act } 2000 \text { (FOIA) } \\
\text { cited as a reason for rejecting } \\
\text { the FGM FOIA request }\end{array}$ & $\begin{array}{l}\text { Number of UK Police } \\
\text { Authorities citing the Section } \\
\text { of the FOIA as a reason for } \\
\text { rejecting the FOIA request }\end{array}$ & $\begin{array}{l}\text { Percentage (\%) of the total } 45 \\
\text { UK Police Authorities citing the } \\
\text { Section of the FOIA as a reason } \\
\text { for rejecting the FOIA request }\end{array}$ \\
\hline Section 12 & 2 & $4.4 \%$ \\
\hline Section 30 (1) & 2 & $4.4 \%$ \\
\hline Section 30 (2) & 2 & $4.4 \%$ \\
\hline Section 30 (3) & 16 & $35.6 \%$ \\
\hline Section 31 & 4 & $8.9 \%$ \\
\hline Section 31 (1) a & 19 & $42.2 \%$ \\
\hline Section 31 (1) b & 5 & $11.1 \%$ \\
\hline Section 31 (3) & 30 & $66.7 \%$ \\
\hline Section 38 (1) & 1 & $2.2 \%$ \\
\hline Section 40 & 2 & $4.4 \%$ \\
\hline Section 40 (2) & 5 & $11.1 \%$ \\
\hline Section 40 (5) & 5 & $11.1 \%$ \\
\hline
\end{tabular}

Table 6: Sections of the Freedom of Information Act 2000 given for rejecting the FOIA request

Reasons provided for declining the request for information under the FOIA 
Thirty-one (68.9\%) Police Authorities rejected the FGM FOIA request outright - both on initial request and on Appeal. Responses from these 31 Police Authorities were, generally, formulaic with, for example, 23 (51.1\%) of the total 45 Police Authorities who rejected the request citing the same two online news articles from the Daily Telegraph Newspaper and The Week as reasons for declining the FGM data request (The Telegraph 2015) (The Week 2015).

$26(57.8 \%)$ of the total 45 Police Authorities cited the College of Policing Authorised Professional Practice (APP) guidance on "Victims and Witnesses" (College of Policing 2017), and 29 (64.4\%) cited the APP guidance on "Information Management" (College of Policing 2013), as reason(s) for rejecting the request.

Those Police Authorities citing Section 31(1) and/or Section 30(3) of the FOIA stated that these sections exempt information from disclosure if disclosure which would prejudice the prevention/detection of crime, and/or the apprehension/prosecution of offenders. Such provisions also exempt the authority from the duty to confirm or deny whether any information is held which is subject to criminal investigations. On this basis they often refused to confirm or deny whether they had any data on mandatory reporting of cases of FGM at all. The logical inference is that if there are a small number of cases, they might fall into this category. However, it does not explain why the HSCIC reports have not progressed to an investigation nor why the general nature of a report cannot be de-identified.

Those Police Authorities citing Section 40(2) of the FOIA, state that those provisions meant they could not disclose third party personal information. Appeal requests all reinforced that it was general, anonymous statistical data on number of FGM reports that was being requested, rather than any third party personal identifying information. 
South Yorkshire and West Midlands were distinct from the other Police Authorities in that they declined to comply with the FOIA request using the provisions set out in Section 12 of the FOIA as a reason for rejection, citing that the cost in pounds (GBP) and hours of retrieving the relevant data on FGM would far exceed the appropriate limit.

Another reason cited by Police Authorities as a reason to decline with FOIA request was "defense of the public interest". This was loosely defined by those Police Authorities as 'protecting alleged victims of FGM', and subsequently those Police Authorities outline a view that the FOIA request itself endangered alleged victims.

Arguing that that the publication of FGM data could alert those who suspect they may be under investigation and could therefore lead to negative outcomes for the victim was also cited as a reason for refusing the FOIA request. For example, given the small number of offences recorded by each authority in this area of crime each month, it was suggested that if an offender committed an offence in November 2014 and became aware that the local police had received no report of FGM in November 2014 and December 2014, they could reasonably assume that the victim had not reported the offence to police. Conversely, if the offender had committed an offence in November 2014, it was suggested that the release of any information showing any offence recorded in November 2014 or December 2014 would signal that the victim or another person, had reported the incident to police.

A further argument used to decline the FOIA request was that these disclosures could give the victim the impression that confidentiality is broken, and thus, allegedly, impact the likelihood of further witnesses or victims coming forward in the future.

\section{Appeals requests}


In the Appeals requests it was argued that requests for FGM data were not plausibly endangering ongoing investigations, or the confidentiality of victims, and rather the public interest lay in the need to complete evaluation of mandatory reporting of FGM prior to implementing mandatory reporting for other forms of abuse.

\section{Summary of negative responses}

In summary, the Police Authorities declining to provide data argued that law enforcement tactics could be compromised, further crime could be enabled, and victims could be placed at risk and feel that confidentiality is broken. 


\section{DISCUSSION}

\section{Transparency}

The ability of front-line professionals and policy-makers to interpret FGM incidence and prevalence data, and respond to the needs of affected women and children, is affected by the secrecy which surrounds the performance of FGM, the complexities of investigation and the absence of significant number of prosecutions.

We recognise that requesting data, where there are a small number of cases, causes concern that it would be used for a private investigation into who had reported what and to put pressure on people not to cooperate with the authorities. However, given that currently there is very little access to data on FGM investigations, we believe there is an unreasonable barrier to measuring the success of community eradication initiatives. It simply cannot be seen whether FGM is being tackled or not nor whether current responses are effective.

\section{Lack of consistent, high-quality data}

Police forces are not collecting data or responding to requests for information in a consistent fashion. For those police forces who did disclose recorded incidents of FGM, it is unclear whether this refers to all reports or accusations, as opposed to those where someone has been formally charged with a crime. Meanwhile at the national level, if the ONS and Home Office aggregate FGM data with other assaults under Category $8 \mathrm{~N}$, then the value of recording the data is actually lost entirely.

\section{Lack of clarity about age that victim was subjected to FGM}

It is not clear from the data we obtained in relation to victims of FGM reportedly aged over 18 years of age, whether the FGM was performed as a child or as an adult. This adds to concerns that the data being recorded (either as a result of individual Mandatory Reporting or 
organisational Mandatory Recording) are not in a format that helps policy-makers and professionals to target preventative strategies towards particular age groups of people, and their communities.

\section{Mismatch between NHS data and Police data}

The HSCIC reports that from October 2014 to October 2015, there were on average 481 new reports of FGM each month across England. By comparison, there were 145 cases of FGM reported by Police Scotland, Greater Manchester Police, and London Metropolitan police combined, for the entire 12 month period of October 2014 to September 2015. This huge mismatch between Health and Social Care Information Centre data and police data suggests that medical reports are not being followed up and the true scale of FGM in England and Wales is not being properly investigated. 


\section{CONCLUSIONS}

The effectiveness of FGM mandatory reporting could provide a useful background to decision making over mandatory reporting for all forms of child abuse. As a testing ground, at present, the conclusion we could reach is that records are made but do not appear to be followed up in significant numbers for the purposes of reporting. We recommend that there should be an across government approach to solve these issues, providing an effective system for linking recording and reporting to allow for meaningful follow up, and for de-identifying data for both public consumption and legal-medical research. To this end, we have three proposals.

\section{Proposals}

1. We propose that FGM data is collected by police forces separately from other assaults, and in such a way that useful data can be extracted without endangering confidentiality. Since some Police Authorities (Metropolitan, Greater Manchester) were able to provide data on FGM reporting, this must be possible. This would also solve the cost burdens identified by South Yorkshire and West Midlands police. Finally, aggregate national data should be collected by a central authority, led by an FGM Commissioner.

2. We propose that NHS data is collected against the same criteria as police data and that what is recorded by clinicians is similarly subject to aggregate analysis. Whilst $\mathrm{HSCIC/NHS} \mathrm{FGM} \mathrm{data} \mathrm{may} \mathrm{not} \mathrm{be} \mathrm{directly} \mathrm{comparable} \mathrm{to} \mathrm{data} \mathrm{on} \mathrm{multi-professional}$ mandatory reporting to the police, any disconnect may provide a veil for those practice FGM. The difference between mandatory recording (NHS) and mandatory reporting (police) data comes down to age. Relevant professionals have a duty of mandatory reporting to police only in relation to girls who are under the age of 18 at the time the concern is raised, whereas $\mathrm{HSCIC}$ makes it mandatory to record the diagnosis of FGM in girls and women of any age. The criteria is more broad, thus $\mathrm{HSClC}$ data picks up 
many more cases of FGM as we have seen, though the benefit of this broader search is unclear. This is why we favour a joint approach in data collection.

3. We propose that new guidance be provided to police forces for responding to requests for information where figures rather than facts are being sought. In our Appeals requests it was argued that requests for FGM data were not plausibly endangering ongoing investigations, or the confidentiality of victims, and rather the public interest lay in the need to complete evaluation of mandatory reporting of FGM prior to implementing any mandatory reporting for other forms of abuse.

We take the view that Point 55 from the UK Government Violence against Women and Girls Strategy 2016 - 2020 requires the development of a meaningful action plan for FGM data but currently the issues we have identified mean that, in our view, mandatory reporting and recording of FGM is currently more symbolic than effective. 


\section{Reflective questions}

In this section we set out a series of reflective questions in relation to the United Kingdom (UK) Nursing and Midwifery Council (NMC) Code ("the Code"), which midwives and other regulated health professionals should find useful when considering how this article on FGM mandatory reporting is relevant to their own professional practice. Whilst the Code may differ in other parts of the world, the clinical scenarios will still be useful to health and social care professionals to consider.

1. At her routine maternity booking appointment Fatima, an Egyptian graduate student, tells her midwife, Mary, that she was 'cut' as a child. How should Mary approach a discussion about the clinical and legal implications of this while maintaining a respectful attitude toward Fatima's cultural heritage and beliefs? (NMC Code: 1.1 Treat people as individuals and uphold their dignity).

2. Fatima is offered de-infibulation between 20-34 weeks gestation. She tells the female obstetrician who performs the procedure that she would like to "be put back as before' following childbirth. The doctor respectfully explains that this is not allowed under UK law. How can the midwife and obstetrician caring for Fatima balance her right to exercise informed choice about her care with the need to comply with legal requirements relating to FGM? (NMC Code: 3.3 Act in partnership with those receiving care, helping them to access relevant health and social care and support when they need it).

3. Fatima gives birth to a beautiful daughter. She admits to the midwife that she would prefer that little Iman not be 'cut' but says that although now resident in the UK, she and her husband will return regularly to visit family and her mother-in-law will insist 
that they follow the old traditions to maintain the family 'honour'. (NMC Code: 5.4 Share necessary information with other healthcare professionals and agencies only when the interests of patient safety and public protection override the need for confidentiality).

4. A colleague tells you that Islam requires all girls to have FGM or they will not be able to marry. You know that FGM is a cultural practice, mainly found in Sub-Saharan Africa, and not associated with any one faith. How would you educate your colleague, and other members of the care team who may be acting from misinformation or prejudice? NMC Code: (3.4 Act as an advocate for the vulnerable, challenging poor practice and discriminatory attitudes and behaviour relating to their care).

5. On a postnatal visit, Fatima and her husband, Salim ask her midwife to help them construct an argument as to why Iman should not be 'cut' when she is a toddler or young girl. You start to explain, aside from the legal implications, some of the serious complications that can affect a woman's urogenital health throughout her life. Salim becomes visibly upset and says that his aunt was banished from the family home because of an obstetric fistula after her first child. She died friendless and alone. He asks if this could have been caused through FGM? (NMC Code 2.6 recognise when people are anxious and in distress and respond compassionately and politely).

6. Can you think of other sections of the NMC code that could relate to each of the above questions, and discuss these?

\section{Key words}


1. Cutting

2. Infibulated state

3. Keloid scar

4. Safeguarding

5. Legislation

6. FGM

\section{Major themes with relevance to midwives}

1. Women and girls in the UK who have experienced FGM are mainly from population groups originating in Sub-Saharan Africa.

2. FGM is associated with serious long-term complications throughout a woman's reproductive life cycle, from pre-menarche to post-menopausal.

3. It is a criminal offense to perform FGM on women of any age in the UK; if a female British resident is under the age of 18 years old, FGM is an offense under British law regardless of where the procedure actually takes place.

4. Health, Social Care and Educational professionals have, since October 2015, had a mandatory duty of care to report any verified or suspected cases of FGM to UK police, thus triggering a multi-agency safeguarding response. 
5. Data on incidence of FGM were requested from all 45 UK police authorities; initially only six responded and half of these stated that no cases had been reported in the 16 months between October 2014 and February 2016. 


\section{AUTHORS' CONTRIBUTIONS}

Professor Rowland devised the concept of the study and conducted the Freedom of Information Act 2000 requests (study design and data collection); Dr Malik analysed the results of the literature search and analysed the results of the Freedom of Information Act 2000 requests; All authors contributed to the manuscript writing and finalisation; Professor Rowland is the guarantor.

\section{CONFLICT OF INTEREST STATEMENTS}

Professor Andrew Rowland has nothing to disclose.

Dr Fiona MacVane Phipps has nothing to disclose.

Dr Yusuf Malik has nothing to disclose.

Felicity Gerry has nothing to disclose.

\section{ROLE OF FUNDING SOURCE}

This study received no funding.

\section{ETHICS COMMITTEE APPROVAL}

This study involved obtaining and analysing information available to any member of the public through the provisions of the Freedom of Information Act 2000, an Act of Parliament designed to enable members of the public to receive information which is then considered to be in the public domain. No identifiable information was - or could have been - obtained through the Freedom of Information Act 2000 requests. No human subjects were used in this research. In those circumstances, ethics committee approval was not sought for this study. 


\section{APPENDIX ONE}

List of UK Police Authorities:

\section{England}

$\underline{\text { Avon and Somerset Constabulary }}$

Bedfordshire Police

$\underline{\text { Cambridgeshire Constabulary }}$

$\underline{\text { Cheshire Constabulary }}$

City of London Police

$\underline{\text { Cleveland Police }}$

Cumbria Constabulary

Derbyshire Constabulary

Devon \& Cornwall Police

Dorset Police

Durham Constabulary

Essex Police

$\underline{\text { Gloucestershire Constabulary }}$

Greater Manchester Police

Hampshire Constabulary

Hertfordshire Constabulary

Humberside Police

$\underline{\text { Kent Police }}$

Lancashire Constabulary

$\underline{\text { Leicestershire Police }}$

Lincolnshire Police

$\underline{\text { Merseyside Police }}$ 
$\underline{\text { Metropolitan Police Service }}$

Norfolk Constabulary

$\underline{\text { North Yorkshire Police }}$

Northamptonshire Police

Northumbria Police

Nottinghamshire Police

$\underline{\text { South Yorkshire Police }}$

$\underline{\text { Staffordshire Police }}$

Suffolk Constabulary

Surrey Police

$\underline{\text { Sussex Police }}$

Thames Valley Police

Warwickshire Police

West Mercia Police

West Midlands Police

$\underline{\text { West Yorkshire Police }}$

$\underline{\text { Wiltshire Police }}$

\section{Northern Ireland}

$\underline{\text { Police Service of Northern Ireland }}$

\section{Scotland}

$\underline{\text { Police Scotland }}$

\section{Wales}

Dyfed-Powys Police 
$\underline{\text { Gwent Police }}$

$\underline{\text { North Wales Police }}$

$\underline{\text { South Wales Police }}$ 


\section{APPENDIX TWO}

Freedom of Information Act 2000: Sections related to Table 6

\section{Section 12}

12 Exemption where cost of compliance exceeds appropriate limit.

(1) Section 1(1) does not oblige a public authority to comply with a request for information if the authority estimates that the cost of complying with the request would exceed the appropriate limit.

(2) Subsection (1) does not exempt the public authority from its obligation to comply with paragraph (a) of section 1(1) unless the estimated cost of complying with that paragraph alone would exceed the appropriate limit.

(3) In subsections (1) and (2) "the appropriate limit" means such amount as may be prescribed, and different amounts may be prescribed in relation to different cases.

(4) The Minister for the Cabinet Office may by regulations provide that, in such circumstances as may be prescribed, where two or more requests for information are made to a public authority-

a. by one person, or

b. by different persons who appear to the public authority to be acting in concert or in pursuance of a campaign, 
the estimated cost of complying with any of the requests is to be taken to be the estimated total cost of complying with all of them.

(5) The Minister for the Cabinet Office may by regulations make provision for the purposes of this section as to the costs to be estimated and as to the manner in which they are to be estimated.

\section{Section 30}

$30 \quad$ Investigations and proceedings conducted by public authorities.

(1) Information held by a public authority is exempt information if it has at any time been held by the authority for the purposes of-

a. any investigation which the public authority has a duty to conduct with a view to it being ascertained-

i. whether a person should be charged with an offence, or

ii. whether a person charged with an offence is guilty of it,

b. any investigation which is conducted by the authority and in the circumstances may lead to a decision by the authority to institute criminal proceedings which the authority has power to conduct, or

c. any criminal proceedings which the authority has power to conduct. 
(2) Information held by a public authority is exempt information if-

a. it was obtained or recorded by the authority for the purposes of its functions relating to-

i. investigations falling within subsection (1)(a) or (b),

ii. criminal proceedings which the authority has power to conduct,

iii. investigations (other than investigations falling within subsection (1)(a) or (b)) which are conducted by the authority for any of the purposes specified in section 31(2) and either by virtue of Her Majesty's prerogative or by virtue of powers conferred by or under any enactment, or

iv. civil proceedings which are brought by or on behalf of the authority and arise out of such investigations, and

b. it relates to the obtaining of information from confidential sources.

(3) The duty to confirm or deny does not arise in relation to information which is (or if it were held by the public authority would be) exempt information by virtue of subsection (1) or (2).

(4) In relation to the institution or conduct of criminal proceedings or the power to conduct them, references in subsection (1)(b) or (c) and subsection (2)(a) to the public authority include references- 
a. to any officer of the authority,

b. in the case of a government department other than a Northern Ireland department, to the Minister of the Crown in charge of the department, and

c. in the case of a Northern Ireland department, to the Northern Ireland Minister in charge of the department.

(5) In this section-

- "criminal proceedings" includes service law proceedings (as defined by section 324(5) of the Armed Forces Act 2006);

- "offence " includes a service offence (as defined by section 50 of that Act).

(6) In the application of this section to Scotland-

a. in subsection (1)(b), for the words from "a decision" to the end there is substituted " a decision by the authority to make a report to the procurator fiscal for the purpose of enabling him to determine whether criminal proceedings should be instituted ",

b. in subsections (1)(c) and (2)(a)(ii) for "which the authority has power to conduct" there is substituted " which have been instituted in consequence of a report made by the authority to the procurator fiscal ", and 
c. for any reference to a person being charged with an offence there is substituted a reference to the person being prosecuted for the offence.

\section{Section 31}

\section{Law enforcement.}

(1) Information which is not exempt information by virtue of section 30 is exempt information if its disclosure under this Act would, or would be likely to, prejudice-

a. the prevention or detection of crime,

b. the apprehension or prosecution of offenders,

c. the administration of justice,

d. the assessment or collection of any tax or duty or of any imposition of a similar nature,

e. the operation of the immigration controls,

f. the maintenance of security and good order in prisons or in other institutions where persons are lawfully detained,

g. the exercise by any public authority of its functions for any of the purposes specified in subsection (2), 
h. any civil proceedings which are brought by or on behalf of a public authority and arise out of an investigation conducted, for any of the purposes specified in subsection (2), by or on behalf of the authority by virtue of Her Majesty's prerogative or by virtue of powers conferred by or under an enactment, or

i. any inquiry held under the Inquiries into Fatal Accidents and Sudden Deaths etc. (Scotland) Act 2016 to the extent that the inquiry arises out of an investigation conducted, for any of the purposes specified in subsection (2), by or on behalf of the authority by virtue of Her Majesty's prerogative or by virtue of powers conferred by or under an enactment.

(2) The purposes referred to in subsection (1)(g) to (i) are-

a. the purpose of ascertaining whether any person has failed to comply with the law,

b. the purpose of ascertaining whether any person is responsible for any conduct which is improper,

c. the purpose of ascertaining whether circumstances which would justify regulatory action in pursuance of any enactment exist or may arise, 
d. the purpose of ascertaining a person's fitness or competence in relation to the management of bodies corporate or in relation to any profession or other activity which he is, or seeks to become, authorised to carry on,

e. the purpose of ascertaining the cause of an accident,

f. the purpose of protecting charities against misconduct or mismanagement (whether by trustees or other persons) in their administration,

g. the purpose of protecting the property of charities from loss or misapplication,

h. the purpose of recovering the property of charities,

i. the purpose of securing the health, safety and welfare of persons at work, and

j. the purpose of protecting persons other than persons at work against risk to health or safety arising out of or in connection with the actions of persons at work.

(3) The duty to confirm or deny does not arise if, or to the extent that, compliance with section 1(1)(a) would, or would be likely to, prejudice any of the matters mentioned in subsection (1).

\section{Section 38}

\section{$38 \quad$ Health and safety.}


(1) Information is exempt information if its disclosure under this Act would, or would be likely to-

a. endanger the physical or mental health of any individual, or

b. endanger the safety of any individual.

(2) The duty to confirm or deny does not arise if, or to the extent that, compliance with section 1(1)(a) would, or would be likely to, have either of the effects mentioned in subsection (1).

\section{Section 40}

\section{Personal information.}

(1) Any information to which a request for information relates is exempt information if it constitutes personal data of which the applicant is the data subject.

(2) Any information to which a request for information relates is also exempt information if-

a. it constitutes personal data which do not fall within subsection (1), and

b. either the first or the second condition below is satisfied.

(3) The first condition is- 
a. in a case where the information falls within any of paragraphs (a) to (d) of the definition of "data" in section 1(1) of the Data Protection Act 1998, that the disclosure of the information to a member of the public otherwise than under this Act would contravene-

i. any of the data protection principles, or

ii. section 10 of that Act (right to prevent processing likely to cause damage or distress), and

b. in any other case, that the disclosure of the information to a member of the public otherwise than under this Act would contravene any of the data protection principles if the exemptions in section 33A(1) of the Data Protection Act 1998 (which relate to manual data held by public authorities) were disregarded.

(4) The second condition is that by virtue of any provision of Part IV of the Data Protection Act 1998 the information is exempt from section 7(1)(c) of that Act (data subject's right of access to personal data).

(5) The duty to confirm or deny-

a. does not arise in relation to information which is (or if it were held by the public authority would be) exempt information by virtue of subsection (1), and

b. does not arise in relation to other information if or to the extent that either- 
i. the giving to a member of the public of the confirmation or denial that would have to be given to comply with section 1(1)(a) would (apart from this Act) contravene any of the data protection principles or section 10 of the Data Protection Act 1998 or would do so if the exemptions in section $33 \mathrm{~A}(1)$ of that Act were disregarded, or

ii. by virtue of any provision of Part IV of the Data Protection Act 1998 the information is exempt from section 7(1)(a) of that Act (data subject's right to be informed whether personal data being processed).

(6) In determining for the purposes of this section whether anything done before 24th October 2007 would contravene any of the data protection principles, the exemptions in Part III of Schedule 8 to the Data Protection Act 1998 shall be disregarded.

(7) In this section-

- "the data protection principles" means the principles set out in Part I of Schedule 1 to the Data Protection Act 1998, as read subject to Part II of that Schedule and section 27(1) of that Act;

- "data subject" has the same meaning as in section 1(1) of that Act;

- "personal data" has the same meaning as in section 1(1) of that Act. 


\section{REFERENCES}

Albert J, Bailey E, Duaso M. 2015. Does the timing of deinfibulation for women with type 3 female genital mutilation affect labour outcomes?. British Journal of Midwifery. 23(6): 430-437.

Amnesty International's Contribution to the Consultation on an EU Strategy for Combating Violence

Against Women 2011-2015 [Internet]. 2011. Amnesty International EU Office [cited 2017 Oct 25].

Available at http://www.amnesty.eu/static/documents/2010/aicontribvaw.pdf

Anon., n.d. UK Police Forces. [Online]

Available at: $\underline{\text { https://www.police.uk/forces/ }}$

[Accessed 2510 2017].

Bewley S, Creighton S, Momoh C. 2010. Female genital mutilation. BMJ. 340: 27-28.

Authorised Professional Practice (APP) guidance on "Information Management" [Internet]. 2013. College of Policing [cited 2017 Oct 25]. Available at http://www.app.college.police.uk/app-content/informationmanagement/

Authorised Professional Practice (APP) guidance on "Victims and Witnesses" [Internet]. 2017. College of Policing [cited 2017 Oct 25]. Available at https://www.app.college.police.uk/app-

content/investigations/victims-and-witnesses/

Cook K. 2016. Female Genital Mutilation in the UK Population: A Serious Crime. The Journal of Criminal Law. 80(2): 88-96. 
Reporting and acting on child abuse and neglect - Government Consultation [Internet]. 2016.

Department for Education and Home Office [cited 2018 Jan 10]. Available at

https://www.gov.uk/government/consultations/reporting-and-acting-on-child-abuse-and-neglect

Fernando A. 2007. Strategies in the management of child maltreatment: should reporting be mandatory or voluntary. The Ceylon Medical Journal. 52(1): 1-3.

UK Parliament. 2016. Ending Violence against Women and Girls Strategy 2016 - 2020, s.I.: UK Government.

HSCIC (Health and Social Care Information Centre). 2017. Female Genital Mutilation (FGM) Enhanced Dataset- April 2016 to March 2017, Experimental Statistics. [Online]

Available at: http://digital.nhs.uk/pubs/fgm1617

[Accessed 11 December 2017].

Macfarlane A, Dorkenoo E. 2015. Prevalence of Female Genital Mutilation in England and Wales: National and local estimates. [Internet]. City University London [cited 2017 Dec 01].

Available from https://tinyurl.com/fgmstat15

Mathews B. 2011. Exploring the contested role of mandatory reporting laws in the identification of severe child abuse and neglect. Law and Childhood Studies, 14(19): 302-338. 
NHS England. 2015. Female Genital Mutilation (FGM) Mandatory reporting duty [Internet]. Department of Health [cited 13 Apr 2018]. Available from:

https://assets.publishing.service.gov.uk/government/uploads/system/uploads/attachment_data/file/52 5405/FGM_mandatory_reporting_map_A.pdf

Project Azure [Internet]. 2010. Metropolitan Police [Cited 29 December 2017]. Available from: http://www.policeauthority.org/Metropolitan/committees/cep/2010/101104/08/index.html Advice and Information about Female Genital Mutilation [Internet]. 2018. Metropolitan Police [Cited 15 January 2018]. Available at: https://www.met.police.uk/advice-and-information/child-abuse/femalegenital-mutilation-fgm/

Moffat P. 2017. Tackling FGM in the UK. Journal of Health Visiting, 5(7): 317.

NHS England, 2015. The Health and Social Care Information Centre (Female Genital Mutilation) Directions 2015 [Internet]. 2015. NHS England [cited 2017 Sep 01]. Available from https://tinyurl.com/hscicfgm1

Female genital mutilation (FGM) [Internet]. 2018. (NSPCC) National society for the prevention of cruelty to children [cited 2018 Mar 10]. Available at https://www.nspcc.org.uk/preventing-abuse/child-abuseand-neglect/female-genital-mutilation-fgm/

Population Estimates for UK, England and Wales, Scotland and Northern Ireland [Internet]. 2017. Office for national statistics [cited 2018 Nov 20]. Available at 
https://www.ons.gov.uk/peoplepopulationandcommunity/populationandmigration/populationestimate s/datasets/populationestimatesforukenglandandwalesscotlandandnorthernireland

Rashid M, Rashid M. 2007. Obstetric management of women with female genital mutilation. The Obstetrician \& Gynaecologist. 9: 95-101.

Rogers J. 2015. The first prosecution for FGM. Criminal Law and Justice Weekly. 179(9).

Simpson J, Robinson K, Creighton S, Hodes D. 2012. Female genital mutilation: the role of health professionals in prevention, assessment, and management. BMJ. 344(e1361).

NHS doctor cleared in less than 30 minutes in first FGM case [Internet]. 2015. The Telegraph [cited 2017 Dec 01]. Available from https://www.telegraph.co.uk/news/uknews/law-and-order/11390629/NHSdoctor-cleared-of-performing-FGM-amid-claims-he-was-used-as-a-scapegoat.html

Women with vaginal piercings 'victims of female genital mutilation' [Internet]. 2015. The Week [cited 2017 Dec 01]. Available from http://www.theweek.co.uk/57224/women-with-vaginal-piercings-victimsof-female-genital-mutilation

Mandatory Reporting of Female Genital Mutilation - procedural information [Internet]. 2016. UK Home Office [cited 2017 Sep 15]. Available at: $\underline{\text { https://tinyurl.com/mandrep16 }}$

Freedom of Information Act [Internet]. 2000. UK Parliament [cited 2017 Oct 25].

Available at: https://www.legislation.gov.uk/ukpga/2000/36/contents 
Female Genital Mutilation Act 2003 [Internet]. 2003 (as amended 2014). UK Parliament [cited 2017 Sep 20]. Available at: https://www.legislation.gov.uk/ukpga/2003/31/contents

Female genital mutilation: abuse unchecked [Internet]. 2016. House of Commons Home Affairs Committee [cited 2017 Dec 29]. Available at https://publications.parliament.uk/pa/cm201617/cmselect/cmhaff/390/390.pdf

Female Genital Mutilation/Cutting: A Global Concern [Internet]. 2016. UNICEF [cited 2017 Sep 22]. Available at https://www.unicef.org/media/files/FGMC 2016 brochure final UNICEF SPREAD.pdf

Understanding and addressing violence against women: female genital mutilation [Internet]. 2012. (WHO) World Health Organisation [cited 2018 Jan 10]. Available at http://apps.who.int/iris/bitstream/10665/77428/1/WHO RHR 12.41 eng.pdf Female Genital Mutilation [Internet]. 2017. (WHO) World Health Organisation [cited 2017 Sep 22]. Available at http://www.who.int/mediacentre/factsheets/fs241/en/ 